\title{
Business Analysis and Product Innovation to Improve SMEs Business Performance
}

\author{
R A M Febrianti*, A S N Herbert \\ Department of Management, Faculty of Economy and Business, Universitas Widyatama, \\ Bandung, Indonesia \\ Email: *adjeng.mariana@widyatama.ac.id
}

\begin{abstract}
Currently, business growth, especially small and medium-sized businesses in Bandung City, Indonesia, has experienced a fairly high increase. In this era of the COVID-19 pandemic, SME players must be able to improve their analytical skills, especially knowledge about business trends. In addition, the innovation factor is also perceived to be very important in order to survive in the face of competition. This study is aimed to understand the influence of business analysis and innovation performance in improving the business performance of small and medium enterprises. This study uses a quantitative method with an explanatory approach to determine how much influence the independent variable has on the dependent variable. Respondents in this study were SMEs in the city of Bandung, especially on Jalan Cikutra. 200 questionnaires were distributed but only 170 were returned. The results in this study are that these two variables have a fairly high influence on business performance. This shows that the variables of business analysis ability and innovation are important factors for SMEs to improve their business performance.
\end{abstract}

\section{Introduction}

Being a profitable company is not enough if the company itself is not growing. This is due to the fact that many companies or business organizations are currently making profits but not growing in quantity, especially in the context of SMEs. According to Singh a business that does not gain growth will not be able to sustain its profits in the long term [1-3]. According to Ngoasong, one of the benefits of business growth is increased income, employee opportunities for advancement, and expansion of distribution channels [4]. There is a strong stigma of why companies or organizations do not grow, as this is due to the reason that the market is so saturated that it is not effective for growth. However, if this stigma is true, it would be a question whether it is possible for products to be more widespread, especially in the context of online business. According to Kotler et al., growth is a mindset [5]. In the context of online business, online business strategies can be carried out in various ways, such as price cuts, price increases, market expansion, and innovation. Each of these methods has obstacles, for example, price cuts will usually always be matched by competitors. It will be difficult to increase prices, especially when economic conditions and expansion are difficult. 

organizations to apply various approaches through social media and develop innovations [6]. For any business, using knowledge to innovate can drive growth and revenue. In this competitive industry, innovation is key in building a sustainable business that can create value, especially for entrepreneurs. For an entrepreneur, the application of technology is the right strategy as a way to get a market. This is as stated by Glomsrød, that the application of technology, especially social media, can expand market segments for business people [7]. Purwanti et al. stated that to be able to grow every business must be able to make four segment movements, namely moving towards competitor segments, creating detailed segments, jumping into new segments, and re-segment the entire market [8]. Previous research has stated that the four segments can have an influence on growth, but there has been no research that applies this to the context of SMEs [9]. For entrepreneurs, especially in the city of Bandung, they need to adapt to technology in order to grow and be competitive, especially in the current digital era.

Transforming from a conventional business to a digital one is expected to drive growth that can generate long-term profits. Various types of SMEs in Bandung City currently have integrated their sales activities through social media. Currently, there are various kinds of products for sale ranging from banner production, food clothing needs, and the handicraft industry. Therefore, the purpose of this study is to find out the factors that can affect business performance by examining the variables of business analysis and product innovation, as well as and to find out how much influence these variables have in explaining business performance. This study is divided into five parts, in the first part is presented on matters relating to the background of the problem, the second part is presented on relevant theories, methods and types of research are presented in part three, and the discussion in the fourth and last part presented the conclusions and suggestions.

\subsection{Business Analysis Ability Concept}

In situations where many organizations offer products of value, the processes within the organization differ from those of competing competitors [10]. Analytical capabilities can draw potential people or organizational value from organizational processes. Analytical skills can also help organizational operational processes find the true potential of processes to support business decisions, especially in product creation [11]. Business analysis ability is a knowledge supporting factor that influences strategy by focusing on what the needs of consumers and products are, which can plan, collect data, analyze data, and present analysis results to decision makers [12]. Therefore, the determination of products and promotions is in the process of analytical ability, starting from data collection, planning, analysis and presentation [13]. To examine the factors in the organization in the process of business analysis capabilities, analyzed three important aspects, namely expertise capability, technology capability, and information capability [14]. Expertise capability is the ability of relevant people to support the strategy. These are skilled people with experience who have a clear understanding of the organization's goals [15].

They are interested in pursuing new knowledge, creative skills, the ability to share knowledge, and apply knowledge to improve or solve problems [16]. Technology capability is a basic resource of organizational information technology. Both are hardware and software, both of which are related to promotional activities, especially on social media [17]. Organizational technology must be conducive to gain access to new knowledge [18]. Technology also provides access that can facilitate between sellers and buyers [19]. 
Information capability is the characteristics of the ability to store or have information as a basis for decision making.

\subsection{Innovation Performance}

Innovation is an important tool for entrepreneurs to create competitive advantage, market opportunities, and business growth driven by change and make a difference in business [20]. In the context of organizational innovation, it is categorized into three categorizations, namely product innovation, process innovation, and strategic innovation [21]. Desyllas defined the results of the methodology developed for use in the production of goods and services using the main objectives of the innovation process [22]. The ability to innovate and develop in different organizational contexts is what many researchers contribute to research on innovation [23]. Organizational context has provided researchers with innovation categorization by bringing Schumpeter's concept to develop and categorize innovations in three categories: product innovation, process innovation, strategic innovation [24]. Herstad defined the results of the methodology developed for use in the production of goods and services, using the main objectives of the innovation process [25]. Innovative performance is the concept of innovative product and process efficiency. Innovation involves the introduction of new or improved products or services to the market and will focus on identifying new customer needs, product quality, and developing strategies that extend to the market effectively.

According to Vanhaverbeke, the focus and results of non-financial innovations are: novelty, economic benefits, and ideal creativity [26]. The process perspective is to increase the speed of product production by innovating new technologies to improve processes and accelerate production [27]. The market view is to increase customer demand and satisfaction for innovative products.

\subsection{Business Performance}

Performance reflects of the company's state of its activities during a certain period and is a result or achievement that is influenced by the company's operational activities. Many companies or business organizations are oriented to produce better performance. Various ways and strategies are formulated in order to optimize better returns. According to Johan and Isfianadewi, performance can be measured by two indicators, namely increased sales volume and rapid response to changes [28]. In addition, Cheah, makes it clear that company performance can be measured using a balanced scorecard approach which is divided into four perspectives, namely finance, customer, internal business processes, and learning and growth [29]. Chen stated that performance is a measure of the level of success of a company in carrying out its goals [30]. For Abbas, performance is the result of work that has a strong relationship with strategic goals [31]. Management must create a communication link to resources for the success of the company as well as assess the extent of the excellence of an organization. In order for companies to obtain good business performance, companies must always update their innovations to achieve excellence so that they can gain excellence.

\subsection{The Influence of Business Analysis on Business Performance}

Business analysis ability is a knowledge supporting factor that influences strategy by focusing on what the needs of consumers and products are, which can plan, collect data, analyze data, and present analysis results to decision makers [12]. Carrying out a business analysis can be started from making plans and collecting relevant data that is related to certain 

detail analysis to help understand about the behavior. Analytical skills can also help organization to find the true potential of processes to support their business decisions, especially in product creation [11]. When the products created by companies are based on a thorough business analysis, this will make the products to be inimitable and highly valued by consumers, which is in accordance with the resource-based view or VRIO theory. This will lead to increased sales volume, which belongs to one of the measurements of performance [28].

\subsection{The Influence of Innovation Performance on Business Performance}

Innovation is one of the most important tools for business people to create competitive advantage, market opportunities, and business growth driven by change and make a difference in business [20]. Currently, a number of studies have discussed about the ability to innovate and develop in different organizational contexts [23] is what many researchers contribute to research on innovation. Performance reflects the company's state of its activities during a certain period. Performance can also be considered as a result or achievement that is influenced by the company's operational activities, which in this regard, is business performance. These days, many companies or business organizations are oriented to produce better performance. Various ways and strategies are formulated in order to optimize better returns. In order to achieve this goal or target, individual and organization need to realize the importance of having the capability to innovate, thus leading to innovation performance (See Figure 1).

\subsection{Conceptual Framework}

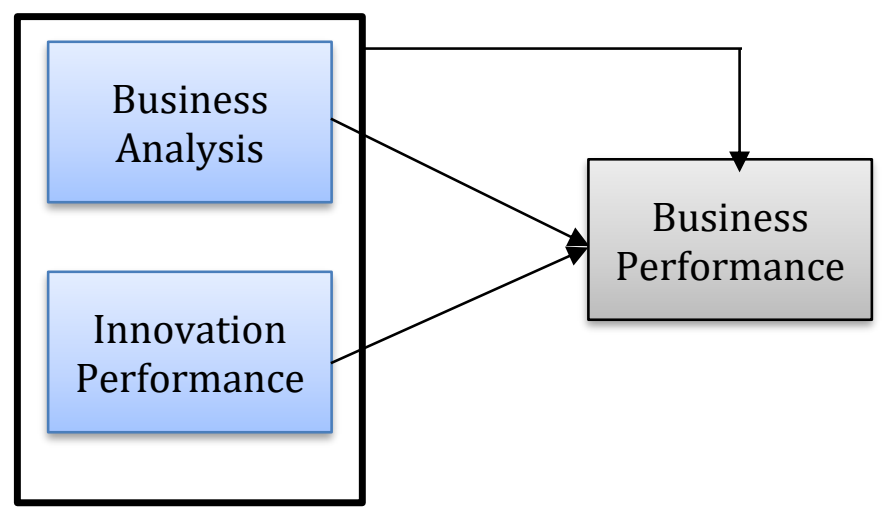

Figure 1. Conceptual Framework

H1. Business analysis ability has a positive effect on Business Performance.

H2. Innovation performance has a positive effect on Business Performance.

H3. Business Analysis Ability and Innovation Performance have a positive effect on Business Performance.

\section{Method}

This type of research is quantitative research with the object of this research containing the points of attention attached to the research subject. This point of concern can be assigned a value and the value will vary (different) from one individual to another. In this study, the research is focused on variables consisting of business analysis and innovation performance on business performance. The data used in this study are secondary and primary data. The 

Jalan Cikutra. For the data collection, 200 questionnaires were distributed and only 170 were returned. Data analysis is then carried out using descriptive statistics, classical assumption test consisting of normality test, multicollinearity test, heteroscedasticity test, autocorrelation test, and multiple linear regression test consisting of hypothesis testing and coefficient test determination using SPSS 25 software.

\section{Results and Discussion}

\subsection{Respondents' Profile}

The results of the distribution of 170 respondents indicate that the results obtained are as follows (Table 1):

Table 1. Respondent profile

\begin{tabular}{ccc}
\hline Respondent Profile & & Percentage \\
\hline Gender & Male & $68 \%$ \\
& Female & $32 \%$ \\
Age & 20-30 year & $22 \%$ \\
& $30-40$ year & $20 \%$ \\
Kind Of Business & $40-50$ year & $58 \%$ \\
& Convection & $30 \%$ \\
& Handicraft & $10 \%$ \\
& Processed Food & $60 \%$ \\
\hline
\end{tabular}

The table above shows that the respondents are $68 \%$ male and $32 \%$ female. This shows that the respondents are more dominated by men when compared to women. The majority of respondents in the study were aged 40-50 years and most of them were in the type of food processing business. The city of Bandung is known as a culinary city; therefore, the majority of SMEs in Bandung are processed foods. The results of the descriptive analysis test can be seen in the table below:

Table 2 shows that the variables of business analysis, innovation performance and business performance are in the good category. This shows that the respondents give good responses to the research variables. The normality test is as follows:

Table 2. Descriptive Analysis Results

\begin{tabular}{cccc}
\hline No & Variable & Percentage Average Score & Interpretation \\
\hline 1 & Business Analysis & $75,47 \%$ & Good \\
2 & Innovation performance & $75,17 \%$ & Good \\
3 & Business performance & $76,81 \%$ & Good \\
\hline
\end{tabular}

In Table 3 it can be seen that the significance value is $0.0058>0.05$. So it can be concluded that the data used is normally distributed. The multicollinearity test is as follows: 
Table 3. Normality test

\begin{tabular}{lcc}
\hline \multicolumn{3}{c}{ One-Sample Kolmogorov-Smirnov Test } \\
\hline \multirow{N}{*}{ Normal Parameters ${ }^{\mathrm{a}, \mathrm{b}}$} & & Unstandardized Residual \\
& Mean & 170 \\
& Std. Deviation & .0000000 \\
Most Extreme Differences & Absolute & 1.06319280 \\
& Positive & .044 \\
& Negative & .033 \\
Test Statistic & &,- 044 \\
Asymp. Sig. (2-tailed) & & .044 \\
a. Test distribution is Normal & & $.058^{\mathrm{c}}$ \\
b. Calculated from Data & \\
c. Lilliefors Significance Correction. & \\
\hline
\end{tabular}

In Table 4 it can be seen that the independent variable has a tolerance value of not less than 0.10. The value of Variance Inflation Factor (VIF) also shows that the independent variable has a VIF value of not more than 10 . So, it can be concluded that the independent variable does not occur multicollinearity.

Table 4. Multicollinearity test

\begin{tabular}{cccc}
\hline \multicolumn{3}{c}{ Coefficients* } \\
\hline \multirow{2}{*}{1} & Model Collinearity Statistics \\
& Business analysis & Tolerance & VIF \\
a. Dependent Variable: Business performance & .550 & 1.818 \\
& Innovation performance & .738 & 1.354 \\
\hline
\end{tabular}

\subsection{Regression Test Results}

From the output above, it is known the intercept value and regression coefficient so that a multiple linear regression equation can be formed as follows (Table 5):

$\mathrm{Y}=6.013+0.271 \mathrm{X} 1+0.216 \mathrm{X} 2+\mathrm{e}$

Table 5. Regression test

\begin{tabular}{|c|c|c|c|c|c|c|}
\hline \multirow{2}{*}{\multicolumn{2}{|c|}{ Model }} & & $\begin{array}{l}\text { Unstandardized } \\
\text { Coefficients }\end{array}$ & $\begin{array}{c}\text { Standardized } \\
\text { Coefficients }\end{array}$ & & \\
\hline & & B & Std. Error & Beta & $t$ & Sig. \\
\hline \multirow[t]{3}{*}{1} & (Constant) & 6,013 & 1,497 & & 4,038 & 0,000 \\
\hline & Business analysis & 0,271 & 0,064 & 0,250 & 3,334 & 0,001 \\
\hline & Innovation performance & 0,216 & 0,073 & 0,179 & 2,708 & 0,014 \\
\hline
\end{tabular}

The above equation can be interpreted as follows: 

the business performance variable will be worth 6.013 units, thus it can be seen that the regression lines intersect the $Y$ axis at 6.013 points.

$\mathrm{b} 1=0.241$ means that if the business analysis increases by one unit while the other variables are constant, then the business analysis variable will increase by 0.241 units.

$\mathrm{b} 2=0.286$ means that if celebrity innovation performance increases by one unit while other variables are constant, then the innovation performance variable will increase by 0.286 units.

\subsection{Partial and Simultaneous Hypothesis Testing}

From the results of the acquisition of the values above, it can be seen that the $t$-count value obtained by the variable BA is $3.334>t$ table (1.97214), in accordance with the criteria for testing the hypothesis that Ho is rejected and Ha is accepted. This means that partially, the business analysis (BA) variable has a significant effect on business performance. The value for innovation performance was obtained at $2.708>\mathrm{t}$ table (1.97214), in accordance with the criteria for testing the hypothesis that Ho was rejected and Ha was accepted. This means that partially, the variable innovation performance (IP) has a significant effect on the business performance of SMEs in the city of Bandung. The simultaneous testing is as follows (Table 6):

Table 6. Simultaneous test results

\begin{tabular}{ccccrcc}
\hline & Model & Sum of Squares & df & Mean Square & F & Sig. \\
\hline \multirow{2}{*}{1} & Regression & 352,657 & 3 & 117,552 & 28,714 & $0,000^{\mathrm{b}}$ \\
& Residual & 804,363 & 196 & 4,104 & & \\
& Total & 1157,020 & 199 & & & \\
\hline
\end{tabular}

a. Predictor: (Constant), Innovation performance, Business analysis

b. Dependent Variable: Business performance

Source: Processed data 2021

Based on the ANOVA test, the calculated F value was 28.714 with a significant value of 0.000 . From the calculation of the F table, namely at the level of $=0.05, \mathrm{df1}=\mathrm{k}-1=4-1=3$, and df2 $=\mathrm{n}-\mathrm{k}=200-4=196$, the F table is 2.65 . So, when compared, F count $>\mathrm{F}$ table, which is $22.821>2.65$, so it can be concluded that the business analysis and innovation performance variables simultaneously affect business performance in small and medium enterprises (SMEs) in the city of Bandung.

\subsection{Coefficient of Determination Test}

From the calculation results, it is obtained that the coefficient of determination is 0.712 , which means that the influence of the two independent variables on the dependent variable is $71.2 \%$. Meanwhile, $28.8 \%$ or the rest is influenced by other variables not examined in this study. These results indicate that the two variables, namely business analysis and innovation performance, have a strong enough influence on the business performance of SMEs in the city of Bandung.

\subsection{The Effect of Business Analysis on the Business Performance of SMEs in Bandung City}

In this study, responses to questions regarding business analysis were in the good category, meaning that small and medium-sized businesses in Bandung have the ability to conduct business analysis that includes product trends and media promotions. It can be understood given that currently the media social media has become a necessity for consumers to seek 

have been described previously, each of the indicators answered by respondents show positive value. Based on the results of partial hypothesis testing or the t-test that has been carried out, it can be concluded $\mathrm{H} 1$ is accepted, meaning that it is important for business people, especially in the context of online business to maintain relationships and expand networks to remain competitive in the face of competition. This result is also supported by Pourkhani's research, [11] that an organization's ability to conduct business analysis can improve the performance of the business itself.

\subsection{The Effect of Innovation Performance on the Business Performance of SMEs}

In this study, the responses regarding the performance of innovation are in the good category. This shows that respondents are well aware that in order to remain competitive in the face of competition, innovation is needed, especially in relation to the application of social media. This has become one of the strategies for business people, especially in the context of online business. It can be seen from the results of the calculation of respondents' responses that have been described previously, each of the indicators proposed is included in the good category. Based on the results of partial hypothesis testing or the t-test that has been carried out, it can be concluded that H1 is accepted. This is also supported by research conducted by Sousa-Zomer [32] that businesses that innovate can improve the performance of the business itself.

\subsection{The Effect of Business Analysis and Innovation Performance on the Business Performance}

Based on the results of simultaneous hypothesis testing that has been done, it can be concluded that the two independent variables, namely business analysis and innovation performance, have a simultaneous effect on business performance in SMEs in the city of Bandung. In the ANOVA results, the conclusions that can be obtained show that the innovation performance variable is a variable that has an important influence on business success, especially SMEs in building competitive advantage. These results also show a conformity with Agwu's research [12] that business analysis capabilities are one of the factors in building sustainable business performance, as well as Gallego-Alvarez's research [13] which states that innovation is important in improving business performance.

\section{Conclusion}

The results of this study reveal that the current business growth, especially small and medium business actors in the city of Bandung, has experienced a fairly high increase. In this era of the COVID-19 pandemic, SMEs must be able to improve their business analysis skills, especially regarding business trends. In addition, the innovation factor is also felt to be very important in order to survive in business competition. Therefore, every business actor, especially SMEs, must review the strategy they will choose. In this study, the role of business analysis skills and innovation has a high enough influence in building business performance. The development of consumer behavior models in online business is a challenge for academics that is highly expected by online marketers. However, the model tested in this study illustrates that in today's business context, the innovation variable is an important factor. Therefore, suggestions for companies or organizations to always maintain and develop their innovations in order to gain knowledge that can be used as the ability to compete. As for further researchers, the findings of this study are only limited to two variables, then future researchers 


\section{References}

[1] Singh, S. K. (2020). Corporate growth, sustainability and business ethics in twenty-first century. Journal of Management and Governance, 24(2), 303-305.

[2] Ponkratov, V. (2019). Productivity and Economic Growth by Using Business Management Based on the E-marketing: Evidence from developed and developing countries, 20002018. Industrial Engineering and Management Systems, 18(3), 463-473.

[3] Wannakrairoj, W., \& Velu, C. (2021). Productivity growth and business model innovation. Economics Letters.

[4] Ngoasong, M. Z. (2019). Why Hurry? The Slow Process of High Growth in Women-Owned Businesses in a Resource-Scarce Context. Journal of Small Business Management, 57(1), 40-58.

[5] Kotler, P., Keller, K. L., Ang, S. H., Tan, C. T., \& Leong, S. M. (2021). Marketing management: an Asian Perspective.

[6] Jocevski, M. (2020). Exploring the growth challenge of mobile payment platforms: A business model perspective. Electronic Commerce Research and Applications, 40.

[7] Glomsrød, S. (2018). Business as unusual: The implications of fossil divestment and green bonds for financial flows, economic growth and energy market. Energy for Sustainable Development, 44, 1-10.

[8] Purwanti, P., Sarwani, S., \& Sunarsi, D. (2020). Pengaruh Inovasi Produk Dan Brand Awareness Terhadap Keputusan Pembelian Konsumen Pada PT. Unilever Indonesia. Inovasi.

[9] Hacklin, F. (2018). Strategies for business model innovation: How firms reel in migrating value. Long Range Planning, 51(1), 82-110.

[10] Marchet, G. (2018). Business logistics models in omni-channel: a classification framework and empirical analysis. International Journal of Physical Distribution and Logistics Management, 48(4), 439-464.

[11] Pourkhani, A. (2019). The impact of social media in business growth and performance: A scientometrics analysis. International Journal of Data and Network Science, 3(3), 223-244.

[12] Agwu, M. (2018). Analysis of the impact of strategic management on the business performance of SMEs in Nigeria. Academy of Strategic Management Journal, 17(1).

[13] Gallego-Alvarez, I. (2020). An analysis of business ethics in the cultural contexts of different religions. Business Ethics, 29(3), 570-586.

[14] Hausberg, J. P. (2020). Business incubators and accelerators: a co-citation analysis-based, systematic literature review. Journal of Technology Transfer, 45(1), 151-176.

[15] Müller, S. C. (2018). Sharing electricity storage at the community level: An empirical analysis of potential business models and barriers. Energy Policy, 118, 492-503.

[16] Dubgorn, A. (2019). Analysis of digital business transformation tools. In Proceedings of the 33rd International Business Information Management Association Conference, IBIMA 2019: Education Excellence and Innovation Management through Vision 2020 (pp. 9677-9682).

[17] Wang, H. (2020). Integrated techno-economic modeling, flexibility analysis, and business case assessment of an urban virtual power plant with multi-market co-optimization. Applied Energy, 259.

[18] Elmo, G. C. (2020). Sustainability in tourism as an innovation driver: An analysis of family business reality. Sustainability (Switzerland), 12(15). 
[19] Henseler, J. (2020). Using confirmatory composite analysis to assess emergent variables in business research. Journal of Business Research, 120, 147-156.

[20] Meng, X. (2018). Innovation in construction firms of different sizes: drivers and strategies. Engineering, Construction and Architectural Management, 25(9), 1210-1225.

[21] Bayraktar, C. (2017). Competitive strategies, innovation, and firm performance: an empirical study in a developing economy environment. Technology Analysis and Strategic Management, 29(1), 38-52.

[22] Desyllas, P. (2018). Capturing Value from Innovation in Knowledge-Intensive Business Service Firms: The Role of Competitive Strategy. British Journal of Management, 29(4), 769-795.

[23] Marín, F. V. (2017). Strategies of institutions of higher education for the integration of information and communication technologies and of innovation in the teaching process. A study in the district of Barranquilla, Colombia. Formacion Universitaria, 10(6), 29-38.

[24] Peñalver, A. B. (2018). Innovation management and strategy. Journal of Scientific and Industrial Research, 77(8), 437-441.

[25] Herstad, S. (2018). Innovation strategy choices in the urban economy. Urban Studies, 55(6), 1185-1202.

[26] Vanhaverbeke, W. (2017). The importance of connecting open innovation to strategy. Strategy and Communication for Innovation: Integrative Perspectives on Innovation in the Digital Economy (pp. 3-15).

[27] Henttonen, K. (2017). Open innovation in SMEs: Collaboration modes and strategies for commercialization in technology-intensive companies in forestry industry. European Journal of Innovation Management, 20(2), 329-347.

[28] Johan A., Isfianadewi, D., T. A. A. (2019). Sales Force and Intelligenec Strategic in SMEs Performance: Case Study of Batik's Enterprises in Bringharjo Yogyakarta. Journal of Business Studies and Management Review (JBSMR), 2(2), 112-127.

[29] Cheah, S. (2018). Business model innovation for sustainable performance in retail and hospitality industries. Sustainability (Switzerland), 10(11).

[30] Chen, C. (2018). How business strategy in non-financial firms moderates the curvilinear effects of corporate social responsibility and irresponsibility on corporate financial performance. Journal of Business Research, 92, 154-167.

[31] Abbas, J. (2019). The effects of corporate social responsibility practices and environmental factors through a moderating role of social media marketing on sustainable performance of business firms. Sustainability (Switzerland), 11(12).

[32] Sousa-Zomer, T. T. (2018). Sustainable business models as an innovation strategy in the water sector: An empirical investigation of a sustainable product-service system. Journal of Cleaner Production, 171. 